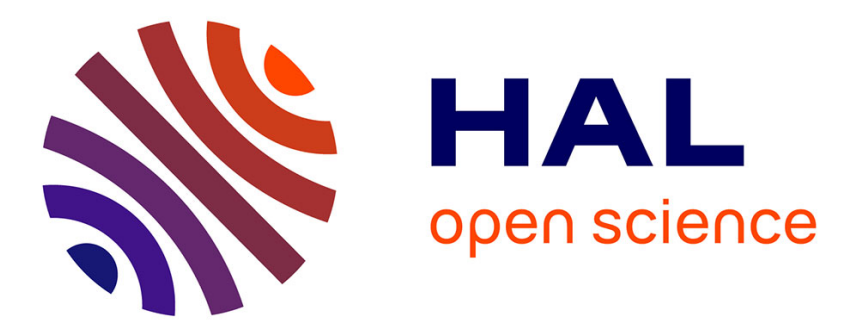

\title{
The "In Situ" Research of the Synthesis of NiMoO4
}

S. Chernov, B. Tolochko, S. Nikitenko

\section{To cite this version:}

S. Chernov, B. Tolochko, S. Nikitenko. The "In Situ" Research of the Synthesis of NiMoO4. Journal de Physique IV Proceedings, 1997, 7 (C2), pp.C2-961-C2-962. 10.1051/jp4:19972102 . jpa-00255159

\section{HAL Id: jpa-00255159 https://hal.science/jpa-00255159}

Submitted on 1 Jan 1997

HAL is a multi-disciplinary open access archive for the deposit and dissemination of scientific research documents, whether they are published or not. The documents may come from teaching and research institutions in France or abroad, or from public or private research centers.
L'archive ouverte pluridisciplinaire HAL, est destinée au dépôt et à la diffusion de documents scientifiques de niveau recherche, publiés ou non, émanant des établissements d'enseignement et de recherche français ou étrangers, des laboratoires publics ou privés. 


\title{
The "In Situ" Research of the Synthesis of $\mathrm{NiMoO}_{4}$
}

\author{
S.V. Chernov, B.P. Tolochko and S.G. Nikitenko* \\ Institute of Solid State Chemistry, 630090 Novosibirsk, Russian Federation \\ * Institute of Catalysis, 630090, Novosibirsk, Russian Federation
}

\begin{abstract}
The formation of the crystal structure of the $\mathrm{NiMoO}_{4}$ high temperature phase in the solid phase reaction $\mathrm{NiO}+\alpha-\mathrm{MoO}_{3} \rightarrow \beta-$ $\mathrm{NiMoO}_{4}$ at $600 \mathrm{C}$ has been "in situ" studied with the high temperature synchrotron technique. We have performed the measurements of the Extended X-ray Absorption Fine Structure (EXAFS) and the X-ray Absorption Near Edge Structure (XANES) at the K-edge of Ni atom in during the $\beta-\mathrm{NiMOO}_{4}$ synthesis. The analysis of the XANES data and the Fourier transtormants of the EXAFS data has led us to the conclusion that at the initial stage of synthesis the nearest oxygen surrounding of $\mathrm{Ni}$ atoms in the final production reaction has got an unique geometry that differs from the octahedral oxygen surrounding of $\mathrm{Ni}$ atoms in the both structures of $\mathrm{NiO}$ and $\beta-\mathrm{NiMoO}_{4}$. At the initial stage of the $\beta-\mathrm{NiMoO}_{4}$ synthesis there is not the final product of the synthesis, but the formation of the $\beta-\mathrm{NiMoO}_{4}$ crystal structure takes place essentially later, contrary to how it has been considered so far. We have concluded that at the original stage of the $\beta-\mathrm{NiMoO}_{4}$ synthesis the some intermediate phase is formed that is characterized with the low concentration of nickel and the low symmetrical geometry for the nearest oxygen surrounding of $\mathrm{Ni}$ atoms .
\end{abstract}

\section{INTRODUCTION}

The properties and the formation of the high-temperature nickel molybdate phase, $\beta-\mathrm{NiMoO}_{4}$, obtained by heating of the powder $\mathrm{NiO}+\alpha-\mathrm{MoO}_{3}$ mixture, have been repeatedly studied. It was claimed in $[1,2]$ that the structure of $\beta-\mathrm{NiMoO} 4$ is isomorphous to that of $\alpha-\mathrm{MnMoO}_{4}$ [3]. According to [4], the synthesis mechanism was considered in the similar systems $\left(\mathrm{MeO}+\mathrm{MoO}_{3}\right.$, where $\left.\mathrm{Me}=\mathrm{No}, \mathrm{Co}, \mathrm{Cd}\right)$ as the formation of the layer of a final product $\left(\beta-\mathrm{NiMoO}_{4}\right.$ in our case) at the contact points of the crystallites of two initial compounds, and further growth of this layer due to diffusion of the atoms of the initial compounds through it and their chemical interaction behind it. But no experimental data to confirm this mechanism have been obtained by now. In the present work we have attempted to study the initial stage of the $\beta-\mathrm{NiMoO}_{4}$ synthesis and verify the crystal structure of an initially formed product by means of $X$-ray absorption experiments. Two methods of $X$-ray absorption spectra analysis have been used for this purpose: XANES and EXAFS. Besides, the peaks in the R-space of EXAFS spectrum were reconstructed for the assumed arrangement of oxygen and molybdenum atoms in the vicinity of the absorbing nickel atoms.

\section{RESULTS}

A powder mixture $\mathrm{NiO}+\alpha-\mathrm{MoO}_{3}$ pressed in a massive copper cell was used as sample in the experiment. The cell was placed on the surface of a heating element. The relation $\mathrm{NiO}: \alpha-\mathrm{MoO}_{3}$ in the sample was equal to $0.1: 1$. A sample of the pure NiO was used for comparison. XANES and EXAFS spectra were obtained at the EXAFS station of the storing ring of the VEPP-3 at the Siberian Synchrotron Radiation Center of the Institute of Nuclear Physics. The electron beam energy was 2 GeV and the current was $100 \mathrm{~mA}$. A double monoblock crystal Si(111) monochromator was used for X-ray monochromatization. The spectra were registered at the K-edge of nickel with a $\sim \mathrm{l} \mathrm{eV} \mathrm{step.} \mathrm{Since} \mathrm{the} \mathrm{measurements} \mathrm{were} \mathrm{carried} \mathrm{out} \mathrm{according} \mathrm{to} \mathrm{the}$ fluorescence technique, the contribution from higher harmonic components of monochromatic radiation had practically no impact on the shape of the spectra.

The selection of the normalized oscillating part of the EXAFS spectrum, $\chi(k)$, followed by the Fourier transformation from $k^{3} \chi(k)$ was carried out using a standard packet of programs, UWXAFS 3.0 [5]. A reference calculation of $\chi(k)$ was carried out for the absorption spectrum at the K-edge of nickel in a well-known structure $\mathrm{NiO}$ in order to determine the energy of the $\mathrm{Ni} \mathrm{K}$-edge. Fourier transformation was carried out in the range $2.5-12$ (A) $)^{-1}$. A strict relationship is known to exist between the positions of radial distribution peaks of the Fourier transform (FT) and distances from an absorbing atom to its nearest neighbors.

In our work both XANES curves and FT of EXAFS data were obtained for the pure NiO and for the mixture (0.1) $\mathrm{NiO}+(1.0) \alpha-\mathrm{MoO}_{3}$ at $25 \mathrm{C}$ and $600 \mathrm{C}$. The distinct difference in the results for these two specimens arises after heating them a little above $600 \mathrm{C}$ for 2 hours (Fig.1, 2). 
After the first small false peak, the second peak (1.7 A) of Fig.1 corresponds to the typical bond of Ni-O ( 2.0 A). But the next peak located at $2.8 \mathrm{~A}$ cannot be explained on the basis of the $\mathrm{B}-\mathrm{NiMoO}_{4}$ structure. In this structure nickel atoms are located inside the oxygen distorted octahedrons like for $\mathrm{NiO}$ structure and the Ni-O distances are 2.1-2.25 A for the first oxygen sphere. The smallest $\mathrm{Ni}-\mathrm{Ni}$ distances are 3.35 and $3.48 \mathrm{~A}$ and the smallest $\mathrm{Ni}-\mathrm{Mo}$ distances are 3.55-3.80 $\mathrm{A}$. Therefore, we inevitably come to the conclusion that it is impossible to explain the third peak in Fig. 1 neither by the coordination of nikel atoms in the structure of $\beta-\mathrm{NiMoO}_{4}$ nor by one in the $\mathrm{NiO}$ structure. The evidence of the conclusion is more vividly seen in the Fig. 2 of XANES spectra at the Ni K-edge recorded "in situ" for the sample when heating the mentioned above mixture to a little above $600 \mathrm{C}$ and keeping it for $2 \mathrm{~h}$ at this temperature.

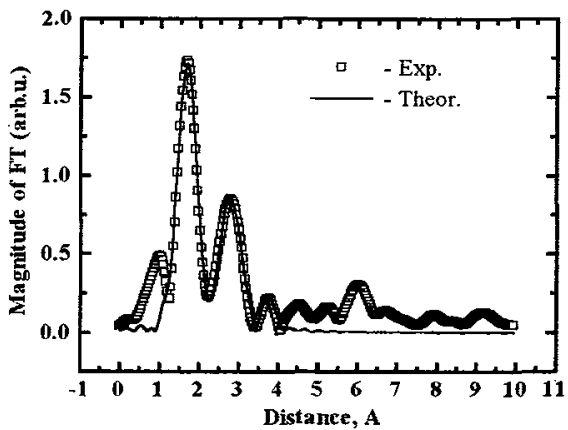

Figure 1: Fourier transforms for mixture $\mathrm{NiO}+\mathrm{MoO}_{3}$ after heating at $600 \mathrm{C}$ for 2 hours.

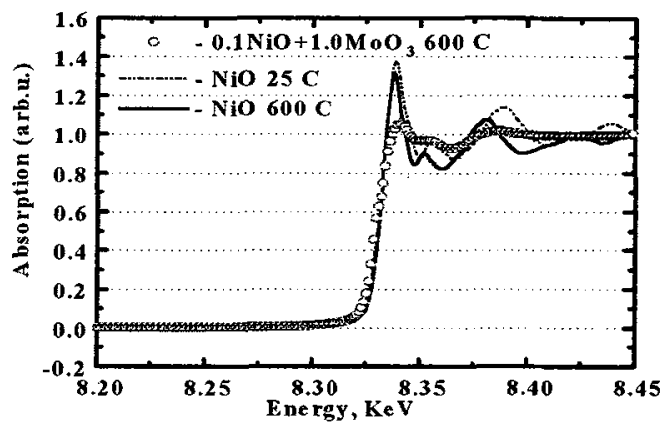

Figure 2: Experimental XANES spectrum at $\mathrm{K}$-edge of $\mathrm{Ni}$ atom.

Fig. 2 exhibits the substantial change of the shape of the spectrum beyond the K-edge of nickel which signifies the substantial change of the geometry of the nearest coordination sphere of nickel at the initial stage of the reaction. The decrease of the intensity of the peak beyond the $\mathrm{K}$-edge can be due to the lowering of the symmetry of the surrounding of $\mathrm{Ni}$ in the new product. Due to the symmetry of the oxygen octahedron there are three equal contributions of three mutually perpendicular polarized photons in the electron transition from the K-level to the continuous spectrum of nickel atom in the NiO structure. Lowering of the symmetry of the nearest oxygen surrounding of nickel splits up these contributions into three different ones with different energies of the absorption photons, and the peak beyond the $\mathrm{K}$-edge of nickel atom is diluted. On the strong of that conclusion, we have made an attempt to analyze the idea of $\mathrm{NiO}$ dissolution during heating in a possible structural modification of molybdenum oxide. It is known that heating of $\mathrm{MoO}_{3}$ in vacuum silicone tube above $800 \mathrm{C}$ followed by cooling in water always leads to the formation of nonhomogeneous product consisting of at least three phases, $\mathrm{MoO}_{3}, \mathrm{MoO}_{2}$, and $\mathrm{Mo}_{4} \mathrm{O}_{11}$ [6]. Structure of $\gamma-\mathrm{Mo}_{4} \mathrm{O}_{11}$ is the most porous among other molybdenum oxides [7]. The high volatility of $\alpha$ $\mathrm{MoO}_{3}$ at $600 \mathrm{C}$ can help the formation of $\gamma-\mathrm{Mo}_{4} \mathrm{O}_{11}$ phase on the surface rather than in the volume. Our Monte-Carlo simulation with pair coulomb potentials of the interaction between the ions have been carried out in order to find possible optimal position of $\mathrm{NiO}$ molecule in the fixed $\gamma-\mathrm{Mo}_{4} \mathrm{O}_{11}$ structure. After it using UWXAFS 3.0 standard program packet the FT curve was calculated and fitted to experimental one. The result is showed in Fig. 1 . The NiO molecules have been placed in the empty pentagonal channels which are stretched continuously along the crystal axis $\mathbf{c}[7,8]$.

\section{CONCLUSION}

From all evidence that at the initial stage the reaction $\mathrm{NiO}+\alpha-\mathrm{MoO}_{3}$ leads to an intermediate phase with the low nickel concentration and the low symmetrical geometry for the nearest oxygen surrounding of Ni atoms, that is different from the final product, $\beta-\mathrm{NiMoO}_{4}$. Perhaps initially, $\mathrm{NiO}$ is dissolved in a modification of molybdenum oxide formed at the surface of $\alpha-\mathrm{MoO}_{3}$ when heated at $600 \mathrm{C}$. This fact and our assumption on the possibility for the formation of the deformed structure of the $\gamma-\mathrm{Mo}_{4} \mathrm{O}_{11}$ phase give: us the possibility to get a good description of the experimental FT of EXAFS data up to 4 A.

\section{References}

[1] Plyasova L.M., Ivanchenko I.Yu., Andrushkevich M.M., Buyanov R.A., Itenberg I.Sh., Hramova G.A., Karakchiev L.P., Kustova G.N., Stepanov G.A., Cailington A.L., and Pilipenko F.S., Kinetika i Kataliz (Russ.) 14, (1973), 1010-1014.

[2] Gleiser M., Larsen R.S., Speiser, and Spetnak:ASTM 171, (1955), 65-68.

[3] Abrahams S.C. and Reddy J.M., J. Chem. Phys. 43, (1965), 2533-2543.

[4] Tkachenko E.V., Zukovskii V.M., Zumal Pricladnoi Himii (Russ.) 46, (1973), 2129-2134.

[5] Stem E.A., Newville M., Ravel B., Yacoby Y., and Haskel D., Pysica B 208\&209, (1995), 117-120.

[6] Kihlborg L., Acta Chem. Scand. 13, (1959), 954-962.

[7] Svensson G., Kihlborg L., Reactivity of Solids, 3, (1987), 33-43. 